\title{
JANE KELSEY, SERVING WHOSE INTERESTS? THE POLITICAL ECONOMY OF TRADE IN SERVICES AGREEMENTS (UNITED KING- DOM: ROUTLEDGE-CAVENDISH, 2008)
}

\section{Maureen Irish*}

Serving Whose Interests is an examination of the General Agreement on Trade in Services [GATS] since its inception in 1995, with several case studies that discuss services trade in specific applications around the world. The scholarship is extensive and detailed. Jane Kelsey, law professor at the University of Auckland, has criticized the pro-market services trade regime in her role as a political activist. In this book, her goals are to make the technicalities of trade rules accessible and to show their effects on people and communities. Throughout, she opposes deregulation and privatization of services and favours shifting the balance back toward "the national, the local and the social." ${ }^{1}$ Services, in her view, are intrinsically social and involve resilient relationships that struggle against the market dynamics of the international trade system. This is a book on GATS by one of its major detractors.

In the book, Kelsey outlines the GATS rules and summarizes the negotiation of the agreement during the lengthy process of the Uruguay Round that concluded with the establishment of the World Trade Organization [WTO]. GATS is one of the agreements included in the single undertaking package that all members of the new organization must accept. Kelsey links GATS to the promotion of market-based development in the IMF, World Bank and United Nations. She discusses the application of the agreement to public services such as the provision of water and electricity. Although GATS does not require governments to deregulate or privatize, she notes that demands for opening these services are often made by other WTO members when individual countries negotiate to accede to the organization. The case study on utilities discusses the opening of the electricity market and infrastructure to private ownership in the Philippines starting in 1988. Services can be difficult to classify, since one project or sector can be disaggregated into various ancillary services such as construction, finance, environmental services, communications, real estate, professional services, computer technology, distribution, transport, logistics and assorted management functions. A case study on the United States - Gambling dispute at the WTO illustrates the complexity of negotiations for services commitments. Antigua won a WTO complaint over the United States' failure to open internet gambling services to international providers, a commitment that the U.S. apparently made through inadvertence, despite its negotiating resources and expertise. ${ }^{2}$ Information technology has permitted outsourcing and the rise of the international call

Faculty of Law, University of Windsor

1 Jane Kelsey, Serving Whose Interests? The Political Economy of Trade in Services Agreements (United Kingdom: Routledge-Cavendish, 2008), 84.

2 The U.S. ban on international access was almost justified under a GATS exception for measures necessary to protect public morals, according to the WTO Appellate Body, but a federal statute permitting internet gambling on horseracing within the U.S. meant that the international ban was unacceptably discriminatory. See Appellate Body Report, United States - Measures Affecting the Cross-Border Supply of Gambling and Betting Services, WT/DS285/AB/R, adopted 20 April 2005.

(2009) 27 Windsor Y.B. Access Just. 
centres around Bangalore, India that Kelsey describes. A subsequent case study shows Fiji's unsuccessful attempt to have GATS rules protect its skilled workers who provide their services as temporary migrants elsewhere and send home remittances that are significant in the Fijian economy. Further case studies deal with education, the UNESCO treaty on cultural diversity, transnational retailers, tourism, oil in Venezuela and the accession of oil-producing Gulf States to the WTO. Kelsey concludes that the market-based ideology reflected in the GATS has failed to serve the interests of societies around the globe, has not overcome the North-South divisions among states and does not provide the certainty and security that transnational businesses seek. In short, she argues, GATS is not in the long-term interests of anyone.

So what is in the General Agreement on Trade in Services that is the source of such harm? GATS Article II contains the main obligation that applies to all services trade apart from specific commitments: the most-favoured-nation obligation, which prevents WTO members from discriminating among other WTO members. Any advantage in services trade granted to one foreign country must be made available immediately and unconditionally to all WTO member countries. Pursuant to Article XVI, if a country makes a market access commitment for particular services, the commitment can be completely open or it can set out the limits of that access, including the total number of service providers, the total value of transactions covered, the number of service operations, the total number of employees, restrictions on the form of legal entity or joint venture that will supply the service and limits on the foreign capital or percentage of foreign ownership involved. If a commitment is made, then Article XVII imposes an obligation of national treatment, requiring that foreign service providers receive the same treatment as domestic service providers, subject to the limits of the commitment. If a commitment is made, then Article VI imposes an obligation of transparency and a requirement that any regulatory measures establishing qualifications not be more burdensome than necessary to assure the quality of the service. Articles XIV and XIVbis set out general exceptions and the exception for essential security interests. The GATS legal framework is based on the idea that market access commitments negotiated over a period of time will gradually lead to more open services trade, in the same way that customs tariff commitments negotiated over several decades under the General Agreement on Tariffs and Trade have gradually lowered the tariffs charged on trade in goods. Services are defined as being provided in one of four modes, according to the manner in which they are delivered: from one territory into another territory (Mode 1), to a service consumer who comes to the territory of the service provider (Mode 2), by a service supplier who has a commercial presence in another territory (Mode 3 ), by a service supplier through the presence of an individual in another territory (Mode 4). GATS does not cover services provided by governments, so long as they are non-commercial and not in competition with other suppliers.

In the case studies, Kelsey criticizes GATS for its potential to limit governmental action if specific commitments are made. The Philippines' privatization of electricity, for example, would be difficult to reverse by future governments if access commitments are made either through GATS or in regional trade agreements. To withdraw a commitment, governments may have to grant other access or pay compensation to several WTO members, as the U.S. has done in order 
to retain its ban on international internet gambling. Commitments made in Mode 3 involve some protection for foreign direct investments in the host country, even in the absence of an investment treaty. While the access commitments made at the beginning of operation of GATS were not extensive, demands for greater access have been made during negotiations since then and are also made when individual countries are in the process of acceding to the WTO. At the start of the Uruguay Round, services were a controversial, new topic that was kept separate from the negotiations on trade in goods. By the time the Round ended, however, they were part of the single undertaking. GATS applies to all WTO members, not just those countries with an interest in further liberalization of services.

Robert Howse has argued that the globalization debate is over. In his view, the antiglobalization movement is no longer focused on defending the national social welfare state against international forces, but has shifted instead to advancing its values as global values. ${ }^{3}$ While that observation is accurate for many commentators and topics, it does not describe Serving Whose Interests. Here, for example, is what Kelsey says about labour rights:

Trade in services agreements threaten the livelihoods of workers through competitive deregulation, foreign investment liberalisation, removal of domestic preferences ... and other core demands. Trade liberalisation in agriculture, industry and natural resources contributes to the push and pull factors that impel workers to migrate internally and offshore, often into highly exploitative services industries. These threats to workers are not matters of core labour standards; they are endemic to a free trade paradigm that perpetuates a grossly unequal international division of labour that is still delineated on traditional social class and North/South lines and denies human beings the fundamental rights to livelihoods, security, voice and dignity. ${ }^{4}$

For Kelsey, there is no room for legitimate international competition. Trade-all trade - threatens fundamental human rights even if core labour standards are respected. If workers at international call centres in India describe their jobs as challenging or satisfying, they have been misled by soft management techniques and corporate indoctrination. ${ }^{5}$ Engagement with international markets is always suspect, in Kelsey's view.

An important question for social justice scholarship is whether public policy ends at national borders or whether Howse is right that the debates now take place within global public policy. Where is the society in which justice is to be judged? On some issues-human rights, humanitarian law, international criminal

3 Robert Howse, “The End of the Globalization Debate: A Review Essay” (2008) 121 Harv. L. Rev. 1528.

4 Supra note 1, 206.

5 Ibid. at 212 . 
law, protection of the environment-social values are commonly framed in global terms, for decision-making at both national and international levels. Issues of the market and economic competition, however, seem more distant from a notion of global citizenship. They are more likely to be described against a presumed background of self-interested states jostling for power in a world unconstrained by social ties. For economic matters, many would agree with Kelsey that the social is only local, never global. Her preferred alternative is specific state-tostate economic negotiations, as in the People's Trade Agreement of Venezuelan President Chávez. While this is consistent with her rejection of international markets, it may not be a convincing solution for many others, including those in poor countries who observe that the most prosperous areas of the world are the market economies (at least at the moment). ${ }^{6}$

Some of Kelsey's views are widely shared by other authors. Noted trade scholar Anna Lanoszka, writing in the institutionalist interdependence tradition of Robert Keohane and Joseph Nye, has also criticized the single undertaking requirement and the power imbalance of WTO accession procedures, both of which can push states to take on excessive market liberalization obligations. She argues that the single undertaking principle should be relaxed in order to provide needed flexibility for WTO members. ${ }^{7}$

A book of this detail and depth is bound to generate a few technical disagreements from others in the field. I have one correction and a few quibbles to mention, none of which negate the merits of the extensive scholarship of Serving Whose Interests. The Libya-Texaco case was the decision of sole arbitrator RenéJean Dupuy, not the International Court of Justice. ${ }^{8}$ In most instances, Kelsey is careful to explain that the private sector rights she criticizes would arise only if there were full GATS access commitments. ${ }^{9}$ In spots, however, she appears to say that Mode 1 imposes a requirement ${ }^{10}$ or that foreign businesses have a right of establishment and national treatment under GATS, ${ }^{11}$ without specifying that these statements are true only if the host state has made an access commitment. Readers who have spent the time to study the summary of GATS provisions in Chapter 1 of the book will not be confused, but others might be.

Written in a style that is readable but not over-simplified, Serving Whose Interests presents an impressive volume of research for evaluation and discussion. The author's approach is anti-GATS, but there is no shortage of other writers on international trade who are equally enthusiastic on the pro-market side. Kelsey's text is a thorough, valuable reference tool. Like all the others, it should be read with a critical eye.

6 Concerning views of economics and law in development theory since 1945, see David Kennedy, “The 'Rule of Law,' Political Choices and Development Common Sense” in David M. Trubek \& Alvaro Santos eds., The New Law and Economic Development: A Critical Appraisal (Cambridge: Cambridge University Press, 2006), 95-173.

7 Anna Lanoszka, The World Trade Organization: Changing Dynamics in the Global Political Economy, (Boulder, Colorado and United Kingdom: Lynne Rienner Publishers, 2009).

8 Supra note 1, 286.

9 Ibid. at 268.

10 Ibid. at 156.

$11 \mathrm{Ibid}$. at 281. 


\section{INSTRUCTIONS TO AUTHORS}

The Windsor Yearbook of Access to Justice is a semi-annual, peer-reviewed, faculty-edited journal. The journal is edited with the highest standards and with the assistance of a prestigious Advisory Board. The scope of the journal, suggested in detail on its web site (www.uwindsor.calwyaj), examines issues about justice and about access to justice from a diversity of disciplinary viewpoints. The editorial board of the Yearbook invites the submission of unsolicited English or French manuscripts in hard copy or electronic formats. Manuscripts should be submitted to: Windsor Yearbook of Access to Justice, Faculty of Law, University of Windsor, 401 Sunset Avenue, Windsor, Ontario, N9B 3P4, Canada or to wyaj@uwindsor.ca

Preparation of Manuscript: Articles generally run from 7000 to 12,000 words although longer articles may on occasion be published. Identification of the author should be removed from the text and footnotes. A separate page containing author's name, affiliation, mailing and email addresses should be provided. An abstract of 100-250 words in English and/or French should be submitted, as should a short form of the title to be used as a running head (maximum of 35 characters). Footnotes should conform to the Canadian Guide to Uniform Legal Citation, $6^{\text {th }}$ Edition, published by the McGill Law Journal. The Guide dispenses with social science citation style (including any requirement for a bibliography). Footnotes should be kept to a minimum and used only when necessary. Substantive comments should be featured in the text, not relegated to the footnotes. Authors of accepted articles will be expected to ensure that the journal's style is followed.

Copyediting and Proofreading: The editors will also copyedit and proofread all articles accepted for publication. Authors will be consulted for any substantial changes. Page proofs of articles will be sent to the lead author but only typographical errors may be corrected.

General: All articles are read blind by at least two reviewers. Because of the effort we ask from our reviewers, the journal cannot consider for publication manuscripts being considered by other journals. A submission to the Yearbook will be taken as an implicit promise that the manuscript has not been concurrently submitted elsewhere, has not been accepted for publication elsewhere and will not be submitted elsewhere so long as it is under consideration by the Yearbook. The copyright policy is stated in detail on the journal's website. 


\section{INSTRUCTIONS AUX AUTEURS}

Le Recueil annuel de Windsor d'Accès à la Justice est une revue qui est publiée deux fois par année par la faculté et pour laquelle les articles soumis sont évalués par des pairs. Il est publié selon les normes les plus élevées et avec l'aide d'un comité consultatif prestigieux. Son champ d'intérêt, décrit en détails sur son site web (www.uwindsor.ca/wyaj), comprend les questions relatives à la justice et à l'accès à la justice traitées des points de vue d'une variété de disciplines. Le comité de rédaction du Recueil invite les auteurs à soumettre des manuscrits non sollicités, en anglais ou en français, en copie papier ou de format électronique. On les soumet au : Recueil annuel de Windsor d'Accès à la Justice, Faculté de Droit, Université de Windsor, 401 avenue Sunset, Windsor, Ontario, N9B 3P4, Canada ou à l'adresse courrielwyaj@uwindsor.ca

Préparation du Manuscrit: Les articles comptent généralement de 7000 à 12000 mots, quoique des articles plus longs peuvent être publiés à l'occasion. Il faut enlever du texte et des notes en bas de page toute forme d'identification de l'auteur et fournir le nom de l'auteur, son affiliation, son adressse postale et son adresse courriel sur une feuille séparée. Il faut soumettre un résumé de 100-250 mots, en anglais et/ou en français, ainsi qu'un titre raccourci à être utilisé comme titre courant (maximum de 35 caractères). Les notes en bas de page doivent être conformes au Manuel canadien de la référence juridique, $\sigma^{e}$ édition, publié par le McGill Law Journal. Le Manuel dispense du style de citation des sciences sociales (y compris toute exigence de bibliographie). Les notes en bas de page devraient être au minimum et n'être utilisées que lorsque cela est nécessaire. Les commentaires de fond devraient faire partie du texte et ne pas être relégués aux notes en bas de page. On s'attend à ce que les auteurs d'articles qui sont acceptés s'assurent de se conformer au style du recueil.

Révision et Correction des épreuves: De plus, les rédacteurs réviseront et corrigeront tous les articles acceptés en vue de leur publication. On consultera les auteurs au sujet de tout changement d'envergure. On enverra les épreuves de page à l'auteur principal mais seules les coquilles peuvent être corrigées.

Général: Au moins deux évaluateurs font la lecture aveugle de tous les articles. Vu l'effort que nous exigeons de nos évaluateurs, le Recueil ne peut pas considérer en vue de publication des manuscrits qui sont en considération par d'autres revues. On tiendra pour acquis que la soumission d'un texte au Recueil est accompagnée d'une promesse implicite que le manuscrit n’a pas été soumis ailleurs en même temps, n’a pas été accepté pour être publié ailleurs et ne sera pas soumis ailleurs aussi longtemps qu'il sera en considération par le Recueil. La politique de droits d'auteur est énoncée en détail sur le site web du recueil. 